\title{
HAK ASASI MANUSIA DI ASIA TENGGARA: SEBUAH EKSPLORASI INFORMATIF ?
}

\author{
V.L. Sinta Herindrasti \\ herindrasti@yahoo.com \\ Universitas Kristen Indonesia
}

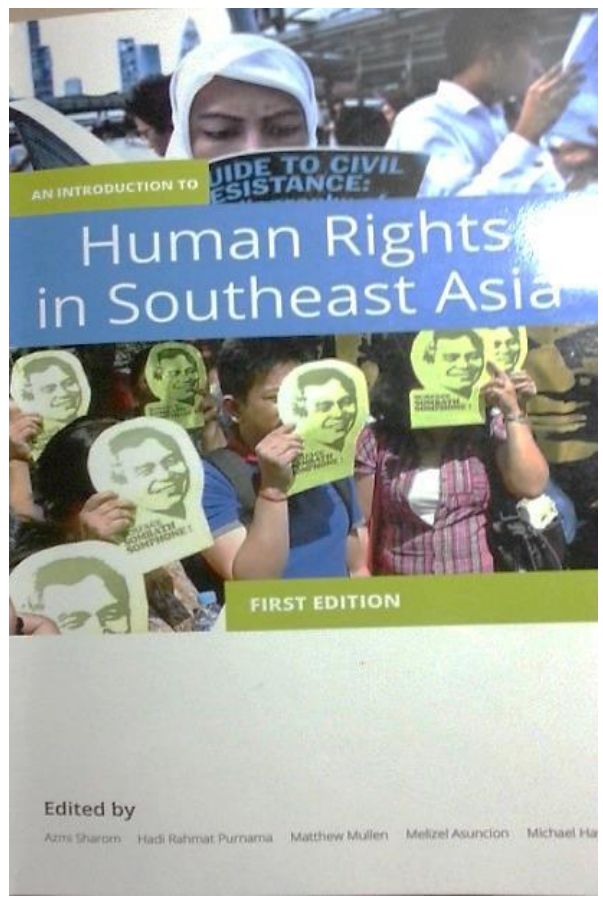

Judul : Introduction to Human Rights in Southeast Asia

Editor : AzmiSharom, Hadi Rahmat Purnama, Matthew Mullen, Melizel Asuncion, Michael Hayes

Penerbit: A Southeast Asian Human Rights Studies Network (SEAHRN), Swedish International Development Cooperation Agency (SIDA), Raoul Wallenberg Institute of Human Rights and Humanitarian Law

Tebal : IX + 191 hal

ISBN :
Sebuah kejutan sekaligus apresiasi luar biasa dengan terbitnya buku teks (textbook) berjudul "An Introduction to Human Rights in Southeast Asia" oleh tim editor Azmi Sharom, Hadi Rahmat Purnama, Matthew Mullen, Melizel Asuncion dan Michael Hayes. Mengapa?

Ada beberapa hal yang perlu digarisbawahi dan menjadi catatan penting terutama untuk penerbitan dengan tujuan sebagai buku teks.

Pertama dari segi visual, buku teks ukuran A4 ini sangat berkualitas. Foto cover tidak 'provokatif' sebagaimana biasanya kita temukan pada buku dengan tema HAM (Hak Asasi Manusia) - dengan cover yang terkadang bernuansa gelap atau hitam, berhuruf kontras, gambarseram - akan tetapi buku ini terbit dengan warna lembut, sejuk dan tidak 'melelahkan' mata. Pilihan paduan warna biru muda, hijau segard dan broken white, font yang 'enak dipandang mata', karena memang serasi untuk dinikmati berlama-lama. Lay out dalam juga sangat terukur sebagaimana buku teks yang tidak seharusnya kaku dan cepat membosankan dengan ketebalan 191 halaman, oenuh dengn konsep dan kasus menyangkut HAM.

Kedua, meskipun dalam pendahuuan buku teks ini ditujukan bagi mahasiswa undergraduate, namun dengan melihat isi (content) rasanya 
melebihi bacaan mahasiswa undergraduate di Indonesia. Skope dan substansi HAM tercakup lengkap dalam buku cukup detail dan eksploratif. Satu sangat jelas dengan melihat "tampilan" adalah buku ini dikerjakan dengan sangat serius oleh orang-orang yang kompeten dan berdedikasi serta didukung oleh lembaga yang bonafide. Dan memang demikian seperti diuraikan oleh salah satu editor dari Universitas Indonesia Hadi Rahmat Purnama dalam Konvensi AIHII V di Hotel Santika Bumi Serpong Damai, Tangerang Selatan. Sebagai sebuah kerja tim buku teks ini memang membutuhkan kesabaran, daya tahan, ketelitian dan yang pasti didukung oleh idealisme dan kompetensi.

Terdiri dari 7 bab, buku ini diawali dengan acknowledgments sebagai apresiasi terhadap keterlibatan berbagai ahli dan lembaga, dimulai dari Koordinator Proyek Matthew Mullen dan Mike Hayes, para penulis yang menyumbangkan karangan (Kontributor) yaitu Ray Paulo J. Santiago, Azmi Sharom, Eko Riyadi, Elizabeth Aguiling-Pangalangan, Hadi Rahmat Purnama, R. Herlambang Perdana Wiratraman, Matthew Mullen, Melizel Asuncion, Michael Hayes dan Muhadi Sugiono; Editor dan fact checkers Benjamin Lee dari Asia Pacific Forum (untuk bab 4 mengenai NHRIs) serta Brian Barbour dari Japan Association for Refugees dan Saya Uematsu Austin dari Brooklyn Law School (untuk bab 6 mengenai pengungsi); tim Editor dan Peneliti Abay Luthra, Douglas Sanders, Gary Cuenoud, Giulia Patane, Huong Ngo, Nicole Ostrand, Jari Trabert, Joel Barredo, Kamarulzaman Askandar, Rhona Smith, Sriprapha Petcharamesree, Uzma Shukrana, Yanuar Samarlan; Proof reader Magdalen Paskell dan Loskaru Sdn Bhd; fotografer cover Lillian Suwanrumpha dan Qiqo Simbol of Focus on the Global South serta dana yang didukung oleh SEAHRN, Sida dan Raoul Wallenberg Institute.

Bab pertama The Fundamentals of Human Rights diawali dengan uraian Situation 1 dan Situation 2 dan memuat 5 sub-bab, yaitu What are Human Rights, Fundamental Human Rights Features and Concepts, Human Rights Law: Rights and Duties, Why Study Human Rigths? - yang kemudian ditutup dengan Summary and Key Points, Questions dan Further Reading. Sangat terstruktur dan informatif.

Bab kedua disusun senada dengan judul The International Human Rights Standards terdiri dari 5 sub-bab yaitu mengulas mengenai diskusi dan debat bagaimana HAM berkonflik dengan kedaulatan negara; Public International Law: The Basics, The Sources of International Law, Background to the Development of International Human Rights Norms, Creating Treaties: An Overview dan Why do states ratify treaties if it gives them legal obligations? Dengan penutup Chapter Summary and Key Points, Questions dan Further Reading.

Bab ketiga mengenai The International Human Rights Treaty meliputi 6 sub-bab yaitu The ICCPR (the International Covenant on Civil and Political Rights), Rights in the ICCPR, Limits to Civil and Political Rights, The ICESCR (the International Covenant on Economic, Social and Cultural Rights), Rights in the ICESCR, Culture and Human Rights beserta penutupnya.

Bab keempat The Protecting Human Rights in SEA terdiri dari 6 subbab yaitu Status of Human Rights Protection in SEA, National Implementation on Human Rights, National Human Rights Institutions, Regional Mechanism, ASEAN HR 
Mechanism dan The Role of NonGovernment Organizations plus penutupnya.

Bab kelima Protection:The International System - Southeast Asian Countries in the UN memuat 4 sub-bab yaitu Human Rights in the Broader United Nations System, the UN Human Rights Body, the Office of High Commissioner for Human Rights (OHCHR), Treaty Bodies dan penutup.

Bab keenam mengenai the Rights of Non-Citizens: Refugees and the Stateless - How to protect Non-Citizens from discrimination and exploitation. Terdiri dari 5 sub-bab Migration in Southeast Asia, The Four Categories of Non-Citizen Rights: An Overview, The Refugee Convention, Refugee populations and protection in Southeast Asia, Stateless Persons serta penutup.

Bab ketujuh The Rights of NonCitizens: Migrant Workers and Trafficked Persons terdiri dari 5 sub-bab Migrant Workers, Migrant Worker Rights Violations, Violations of Migrant Workers Rights, Trafficked Persons, Challenges to Identifying Trafficked Persons dan penutup nya Chapter Summary and Key Points, Questions dan Further reading.

$\begin{array}{llr}\text { Hal-hal positif yang sangat } \\ \text { membantu pembaca } & \text { misalnya } \\ \text { dipaparkan dalam bab pertama } \\ \text { mengenai informasi dasar sesuai }\end{array}$ judulnya yaitu apa itu human rights dan konsep dasar human rights. Pemuatan sistematika International Human Rights Laws (hal 2) sesuai tahun (time line) dalam satu halaman khusus juga sangat mendukung pembaca untuk memahami konvensi HAM secara sistematis, yaitu lahirnya Universal Declaration of Human Rights (UDHR) 1948, disusul dengan International Convention on the Elimination of All Forms of Racial Discrimination (ICERD) 21 Desember 1965, International Covenant on Civil and Publication Rights (ICCPR) 16 Desember 1966 bersama dengan International Covenant on Economic, Social and Cultural Rights, Convention on the Elimination of All Forms of Discrimination against Women (CEDAW) pada 18 Desember 1979, Convention against Torture and Other Cruel, Inhuman or degrading Treatment or Punishment (CAT) 10 Desember 1984, Convention on the Rights of the Child (CRC) pada 20 November 1989, International Convention on the Protection of the Rights of All Migrant Workers and Members of Their Families (ICMW) 18 Desember 1990 dan Convention on the Rights of Persons with Disabilities (CRPD) pada 13 Desember 2006 serta International Convention for the Protection of All Persons from Enforced Disappearance (CPED) pada 20 Desember 2006.

Sesuai dengan judul juga, konteks Asia Tenggara dimunculkan melalui kasus dalam setiap bab misalnya bagaimana situasi "Year Zero" penguasaan Khmer Merah mengarahkan pembaca untuk memahami isu HAM di Kamboja. Tidak hanya situasi historis masa lalu yang digambarkan akan tetapi juga situasi sehari-hari di berbagai kota di Asia Tenggara misalnya adanya fenomena kemiskinan ekstrim dan perlakuan terhadap orang miskin. Pertanyaan HAM menjadi sangat "konkrit" bagaimana prinsip dan konvensi HAM dapat digunakan untuk melindungi masyarakat yang paling rentan ini? Prinsip-prinsip dasar mengenai "being human" juga dijelaskan dalam buku teks ini baru kemudian masuk ke dalam bab-bab berikut mengenai konsepkonsep dan teori. Data yang berkaitan dengan topik tertentu juga diambil dari kasus negara-negara Asia Tenggara, misalnya penerapan hukuman mati di 
Brunei, Kamboja, Indonesia, Laos dan sebagainya.

Jika dari segi substansi buku teks ini sudah sangat memadai, maka kelemahannya justru ditemukan dalam aspek teknis. Daftar isi tidak mencantumkan halaman - sesuatu yang tidak lazim dalam penerbitan sehingga pembaca lebih sulit menemukan bab yang diinginkan. Membolak-balik halaman tanpa menemukan bab yang dicari dapat menghabiskan waktu dan menimbulkan emosi. Kualitas pencetakan juga terasa kurang tajam. Kualitas tinta seperti hasil foto copi/printing yang 'fast economic printing'. Namun huruf masih normal dapat terbaca. Semoga kekurangan teknis ini dapat diperbaiki dalam penerbitan edisi berikut.

Selamat membaca! 